\title{
Cross-country analysis of faecal sludge dewatering
}

Moritz Gold ${ }^{1}$, Hidenori Harada ${ }^{2, *}$, Jean-David Therrien ${ }^{1,3}$, Takahiro

Nishida $^{2}$, Michael Cunningham ${ }^{1}$, Swaib Semiyaga ${ }^{4}$, Shigeo Fujii ${ }^{2}$, Caetano

Dorea $^{3}$, Viet-Anh Nguyen $^{5}$, Linda Strande ${ }^{1}$

${ }^{1}$ Eawag: Swiss Federal Institute of Aquatic Science and Technology, Sandec:

Department of Water, Sanitation and Solid Waste for Development, 8600 Duebendorf, Switzerland

${ }^{2}$ Graduate School of Global Environmental Studies, Kyoto University, Yoshidahonmachi, Sakyo, Kyoto 606-8501, Japan

${ }^{3}$ Département de génie civil et de génie des eaux, Université Laval, 1065 Avenue de la Médecine, Quebec, Canada

${ }^{4}$ Department of Civil and Environmental Engineering, College of Engineering, Design, Art and Technology, Makerere University, P.O. Box 7062, Kampala, Uganda

${ }^{5}$ Institute of Environmental Science and Engineering, Hanoi University of Civil Engineering, 55 Giai Phong Road, Hanoi, Vietnam

*Corresponding: Hidenori Harada, Graduate School of Global Environmental Studies, Kyoto University, Yoshida-honmachi, Sakyo, Kyoto 606-8501, Japan, E-mail:

harada.hidenori.8v@kyoto-u.ac.jp. Tel: +81-(0)75 7535169

\section{Acknowledgements}

This study was funded by the Swiss Development Corporation (SDC), the Japan Society for the Promotion of Science (JSPS) under Grant Number JP 16H02748, and the Fonds de recherche du Québec - Nature et technologies (FRQNT).

This document is the accepted manuscript version of the following article: Gold, M., Harada, H., Therrien, J. D., Nishida, T., Cunningham, M., Semiyaga, S., ... Strande, L. (2018). Cross-country analysis of faecal sludge dewatering. Environmenta1 Technology, 39(23), 3077-3087. https://doi .org/10.1080/09593330.2017.1374472 


\section{Cross-country analysis of faecal sludge dewatering}

Dewatering of faecal sludge (FS) is indispensable for adequate FS management. However, comprehensive knowledge is lacking on FS dewatering performance. This study compared the dewatering performance of FS from different countries and onsite sanitation technologies, to assess influential characteristics on dewatering, and to compare dewatering performance of FS with wastewater sludge. We collected 73 FS samples from septic tanks, lined pit latrines, unlined pit latrines, and johkasou tanks in Uganda, Vietnam and Japan, and 18 samples of wastewater sludge in Switzerland. Capillary Suction Time (CST) and total solids (TS) of centrifuged sludge (\%TS final $_{\text {) }}$ were determined as metrics of dewatering rate and dewaterability, respectively, together with relevant sludge characteristics. Data was analysed by bootstrapping comparison of median results of each sample category, and by bootstrapping multiple regression analysis to quantify the relative importance of sludge characteristics on dewatering performance. Results showed that dewatering rate was significantly different between FS from different technologies, whereas dewaterability was significantly different within the same technology. FS had a significantly lower dewatering rate than wastewater sludge. In contrast, FS dewaterability was greater than wastewater sludge. However, this could be attributed to higher concentrations of sand in FS. Electrochemical properties such as $\mathrm{NH}_{4}-\mathrm{N}$ and surface charge had the strongest correlation to dewatering rate, and solid properties such as sand content and total volatile solids to dewaterability. The results identify potential characteristics that could explain and predict the high variability of FS dewatering performance that is observed in the field.

Keywords: faecal sludge; dewatering rate; dewaterability; bootstrapping; multiple regression analysis

\section{Introduction}

Worldwide, the sanitation needs of 2.7 billion people are met by onsite sanitation technologies [1-2]. Typically, faecal sludge (FS) from these technologies is inadequately managed. FS is "the raw or partially digested, semisolid or slurry resulting from collection, storage or treatment of combinations of excreta and blackwater, with or 
without greywater” that accumulates in onsite sanitation technologies [3]. For example, in Kampala, Uganda; Dar es Salaam, Tanzania; Dakar, Senegal; Hanoi and Danang, Vietnam; and Nonthaburi, Thailand, sanitation needs of 75-100\% people are met by onsite sanitation technologies and $21-82 \%$ of excreta is not safely managed [4-9]. This has significant economic, environmental and public health implications [10, 11].

In urban areas, FS collected by vacuum trucks typically contains more than $95 \%$ water [12-16]. This makes the dewatering of FS indispensable for adequate faecal sludge management. Increased performance of FS dewatering can reduce the amount of FS that needs to be transported, can decrease the required land area or increase the capacities of FS treatment plants, and can improve the resource recovery potential of FS treatment products $[12,13,17]$.

In contrast to FS, comprehensive knowledge is available on the dewatering performance of wastewater sludge in relation to sludge characteristics [18-24]. FS dewatering rates are highly variable between cities and onsite sanitation technologies, and is less efficient than wastewater sludge [13, 25, 26]. For example, in Dakar, Senegal, septic tank FS had a lower dewatering rate compared to literature values for water and wastewater sludge [13]; in Accra, Ghana, public toilet FS had a lower dewatering rate than septic tank FS [26]. FS characteristics that influence dewatering rates and dewaterability have not been reported for different onsite sanitation technologies. Such knowledge could help to improve the design and operation of FS treatment plants. In addition, comparison of FS dewatering rates and dewaterability with wastewater sludge could aid in the transfer of knowledge and technologies from wastewater sludge to FS treatment.

The objective of this study was to quantify and compare the dewatering performance of FS from different countries and onsite sanitation technologies, to assess 
the influential sludge characteristics on the dewatering performance, and to compare the dewatering performance of FS with that of wastewater sludge.

\section{Materials and methods}

\section{Sludge Sampling}

As summarized in Table 1, 73 FS and 18 wastewater sludge samples were collected in Vietnam, Uganda, Japan and Switzerland.

In Uganda, FS samples were collected from 16 lined pit latrines (Lined_UG), 13 septic tanks (Septic_UG) and five unlined pit latrines (Unlined_UG) in Kampala. Lined pit latrines are above or below ground, fully-lined tanks, with no overflow or infiltration [27]. Unlined pit latrines are fully unlined, or partially lined tanks, and thus allow for groundwater inflow or FS infiltration and septic tanks were below ground, fully-lined tanks, with an overflow [28]. Emptying frequencies are highly variable in Kampala, and the average frequency is not known. Lined_UG and Septic_UG samples were collected from vacuum trucks during discharge at Bugolobi Sewage Treatment Works, where FS was also treated with sewage. To obtain representative samples from each vacuum truck, approximately one-liter grab samples were collected four times during discharge and then mixed to one composite sample: once at the beginning, twice in the middle, and once at the end. Unlined_UG samples were collected from manual FS collection service providers during discharge at Bugolobi Sewage Treatment Works. Approximately eight litters of grab samples were collected from the entire FS volume, and mixed to one composite sample.

In Vietnam, FS samples were collected from ten septic tanks of private households (Septic_VN) and four septic tanks of public pay-for-use toilets (Public_Septic_VN) in Hanoi. Emptying frequencies have a high variability, with the 
median interval estimated at seven years [29]. Public_Septic_VN were collected from vacuum trucks discharging at the Cau Dien treatment plant. Septic_VN were obtained through an access port on the top of vacuum trucks with a core sampler.

In Japan, 16 lined pit latrine (Lined_JP) and nine johkasou tank (Johkasou_JP) FS samples were collected. Lined pit latrines in Japan are sealed tanks made out of Fiber-Reinforced Plastics, typically equipped with micro flush toilet pans (200-500 $\mathrm{mL} /$ flush). The FS is collected every few months by vacuum trucks. Johkasou are onsite wastewater treatment units for the treatment of blackwater, or black- and greywater. Johkasou can include different physical, chemical and biological treatments such as contact aeration, anaerobic filter, nitrification and denitrification, phosphorus removal, and chlorination. FS from johkasou is collected once a year by vacuum trucks [30]. Although the sludge from johkasou may be more similar to wastewater sludge as it may include primary and secondary sludge from a biological treatment unit, this paper defined johkasou as FS based on the definition of FS by Strande (2014) [3]. This definition specifies that FS comes from all types of onsite sanitation technologies that are not connected to sewers, and has been widely accepted by the sector. The FS samples were collected from receiving or storage tanks at five FS treatment plants in Kusatsu, Nakatsu, Nose, Togane and Goshogawara.

In Switzerland, six primary (Primary_CH), waste activated (Activated_CH) and anaerobically digested (Digested_CH) wastewater sludge samples were collected. Primary_CH was collected from primary sedimentation tanks, Activated_CH from aeration tanks and Digested_CH from anaerobic digesters. All treatment plants operated with nitrification, denitrification and chemical phosphorus removal. Activated sludge processes included plug flow or sequencing batch reactor configurations. Digested_CH is a mixture of primary sludge and waste activated sludge. Retention times in the 
anaerobic digester were 20-30 days [31]. Samples were collected from wastewater treatment plants in Fallaenden, Bassersdorf, Neuguth, Effretikon, Zurich-Werthoelzli and Uster. Multiple grab samples were collected from each tank and mixed to one composite sample per sample category.

All collected samples were kept refrigerated prior to analyses. FS samples were removed from the refrigerator and left to attain room temperature before analyses.

\section{Sludge Analyses}

Conventional mechanical dewatering such as belt filters or centrifuges remove the free water from sludge [32, 33]. In this study, dewaterability was defined as total solids (TS) following removal of free water during dewatering. It was estimated as $\% \mathrm{TS}$ final, the \%TS of the pellet remaining at the bottom of a $50 \mathrm{~mL}$ centrifuge tube following centrifugation (3000 rpm, 20 minutes) and discarding of the supernatant. \%TS final $_{\text {has }}$ been used for the relative dewaterability of wastewater sludge [23, 34].

Dewatering rate was defined as the rate that free water is released from sludge, and was estimated by Capillary Suction Time (CST (sec)). CST was measured with a meter (304M CST, Triton Electronics Ltd, UK) according to Standard Methods [35]. The CST was normalized to TS (sec/(g TS/L)) to allow comparison of CST results between sludge samples with different TS concentrations [36, 37].

The following characteristics, which potentially influence dewatering performance [18-24], were analyzed: $\mathrm{pH}$, electrical conductivity (EC), temperature, TS, total suspended solids (TSS), total volatile solids (TVS), volatile suspended solids (VSS), ash, sand content, chemical oxygen demand (COD), total nitrogen (TN), ammonium nitrogen $\left(\mathrm{NH}_{4}-\mathrm{N}\right)$, crude protein, surface charge, and particle size distribution. 
TS, TSS, VSS and TVS were analysed according to Standard Methods [35]. Ash was determined as the residue following TVS analysis. Sand content was analyzed gravimetrically after washing the residue of combustion at $550^{\circ} \mathrm{C}$ for two hours with 0.1 mole/L hydrogen chloride [23]. Following washing until the filtrate remained clear, the residue was combusted again at $550^{\circ} \mathrm{C}$ for two hours. COD, TN and $\mathrm{NH}_{4}-\mathrm{N}$ were analyzed with Hach vials according the manufacturer's directions. Crude protein was used as a proxy for EPS (Extracellular Polymeric Substances) and approximated based on an organic nitrogen-to-crude protein conversion factor of 6.5 [38]; organic nitrogen ( $\mathrm{N}_{\text {org }}$ ) was estimated as the difference between TN and $\mathrm{NH}_{4}-\mathrm{N} . \mathrm{pH}$, temperature and EC were measured with handheld $\mathrm{pH}$, temperature and EC probes.

Surface charge was analyzed with small modifications from the colloidal titration method [39, 40]. Samples were diluted to a solution of around $5 \mathrm{~g}$ TS/L. Following, $10 \mathrm{~mL}$ of $2.5 \mathrm{mmol} / \mathrm{L}$ polydiallyldimethylammonium chloride (PDAC) standard solution (WAKO, Osaka, Japan) were added to $90 \mathrm{~mL}$ of distilled water and mixed for one minute. After the addition of $2 \mathrm{~mL}$ of phosphate urea magnesium buffer, $10 \mathrm{~mL}$ of the diluted sample were slowly added and mixed for ten minutes.

Subsequently, a few drops of toluidine blue were added and mix for five minutes and the solution was titrated with $2.5 \mathrm{mmol} / \mathrm{L}$ potassium polyvinylsulfate (PVSK) standard solution (WAKO, Osaka) until a change of color from blue to pink.

Particle size distribution was determined gravimetrically by serial filtration based on Tchobanoglous et al. [41]. Between 15-260 mL of sample were poured in serial through a $1 \mathrm{~mm}, 0.075 \mathrm{~mm}$ and $0.032 \mathrm{~mm}$ sieve and $0.01 \mathrm{~mm}$ filter (Whatman Nuclepore Track-Etched) followed by weighing the dry mass of the residue on each sieve and filter. A sample volume of 2-40 mL was used to allow for complete filtration with the $0.01 \mathrm{~mm}$ filter. The sum of the mass of residues on the sieves and filter for 
each sample had around $\pm 20 \%$ difference compared to the TS for the same sample. Particle sizes were grouped based on Karr and Keinath [19] into settleable (75 $\mu \mathrm{m}<$ particles $<5000 \mu \mathrm{m})$, supracolloidal $(32 \mu \mathrm{m}<$ particles $<75 \mu \mathrm{m})$ and colloidaldissolved $(10 \mu \mathrm{m}<$ particles $<32 \mu \mathrm{m})$ solids.

Large particles in FS interfere with analysis. Therefore, samples were screened through a $5 \mathrm{~mm}$ sieve before all analyses. In addition, samples were homogenized with a blender before analysis of TS, TSS, TVS, sand content, surface charge and \%TS final. $_{\text {. }}$

\section{Data analysis}

Results of sludge analyses in this study were non-parametrically distributed. For data comparison across sample categories, medians were compared with bootstrapping in Python with Anaconda 4.4.0. Bootstrapping was chosen based on the small sample number and the large variability of analyses results [42]. According to Schmid and Huber [42], results are presented as the 75\% confidence interval of the median of 10,000 bootstrapping experiments for each sample category. Significant differences among sample categories were identified by comparing medians in each bootstrapping experiment. Sample categories were considered as significantly different if the median was higher or lower in at least 95\% of bootstrapping experiments. Public_septic_VN and Unlined_UG were excluded in the comparison among sample categories of dewatering rate and dewaterability due to the small sample number.

Stepwise multiple linear regression analysis was conducted with bootstrapping in $\mathrm{R}$ version 3.3 [43] with the package relaimpo version 2.2-2 [44] to evaluate the influence of FS characteristics on CST and \%TS final. To simplify the regression analysis, wastewater sludge and Johkasou_JP were excluded from the regression analysis since these sludges are generated in highly-controlled treatment processes that are very different from conditions in septic tanks and lined or unlined pit latrines. 
Bootstrapping regression analysis was repeated 1,000 times. Prior to regression analysis, characteristics with co-linearity $(-0.7<r<0.7)$ were excluded from the data set with a Spearman's rank correlation matrix (see supplemental material Table S2). Following, 14 characteristics (regressors) were selected for regression analysis, namely: pH, EC (mS/cm), TS (g/L), settleable solids (\%TS), sand content (\%TS), $\mathrm{NH}_{4}-\mathrm{N}$ (mg/g TS), COD (mg/g TS), crude protein (mg/g TS), TVS (\%TS), surface charge (meq/g TS), supracolloidal solids (\%TS), TSS (\%TS), TDS (g/L) and VSS (\%TSS). Two separate bootstrapping multiple regression analyses were conducted: 1 .) with TSS (\%TS), TDS (g/L) and VSS (\%TSS) excluded from regression due to a lack of results for most FS samples from Uganda ( $n=50)$; and 2.) with all 14 characteristics included, but the sample number reduced due to the lack of data in Uganda $(n=40)$. The first analysis is reported in this paper, the second analysis is included in the supplemental material (Figure S1). Characteristics to be included in a regression model and their contributions to $R^{2}$ varied in each bootstrapping experiment. The relative importance, which is the influence of each regressor on $R^{2}$ of the regression model [44], was calculated so that the influence of each parameter on the regression models of CST and \%TS $\mathrm{S}_{\text {final }}$ could be compared. Characteristics that had a median relative importance higher than $10 \%$ were considered as having a significant influence on the regression models.

\section{Results and discussion}

\section{Descriptive statistics of faecal sludge characteristics}

Results of physical and chemical characteristics of FS samples are reported in Table 2, together with values from the literature for comparison. The mean TS, TVS, COD and $\mathrm{NH}_{4}-\mathrm{N}$ were $2.0-3.2 \%, 50.9-73.2 \% \mathrm{TS}, 16.3-33.9 \mathrm{~g} / \mathrm{L}$ and $184-598 \mathrm{mg} / \mathrm{L}$ for septic tank FS samples, and 1.1-2.2\%, 54.0-60.6\%TS, 10.9-21.6 g/L and 1417-1654 mg/L for lined 
pit latrine FS samples. The mean CST and \%TS final were 11-28 sec/(g TS/L) and 1118\% for septic tank FS samples, and 49-63 sec/(g TS/L) and 18-20\% for lined pit latrine FS samples. These results are in reason to those reported in the literature (see Table 2), which could corroborate the results of this study.

Results of this study were not normally distributed, as indicated by the large difference between the mean and median, and had a large variability, as indicated by the standard deviation. The large variability of FS characteristics has also been reported by previous studies (see Table 2). Considering the non-parametric distribution and large variability of results, bootstrapping data analysis was applied in this study as it does not require a parametric distribution and can visualize the variability of results by confidence intervals.

\section{Sludge dewatering performance}

\section{Dewatering rate (CST)}

CST, reported in Figure 1, was used as a metric of sludge dewatering rate. As has been previously reported [13, 25, 26], in this study, FS had a slower dewatering rate compared to wastewater sludge, with the median CST of FS of $19-61 \mathrm{sec} /(\mathrm{g}$ TS/L) $(75 \%$ confidence interval of bootstrapped median), compared to the median CST of wastewater sludge of 3-19 sec/(g TS/L). The median CST was 48-60 sec/(g TS/L) for Lined_UG, 31-61 sec/(g TS/L) for Lined_JP, 22-54 sec/(g TS/L) for Johkasou_JP, 19$38 \mathrm{sec} /(\mathrm{g}$ TS/L) for Septic_UG, 19-29 sec/(g TS/L) for Septic_VN, 10-19 sec/(g TS/L) Digested_CH, 4-5 sec/(g TS/L) for Primary_CH and 3-5 sec/(g TS/L) for Activated_CH. The results indicate that co-treatment of sludge from septic tanks and wastewater sludge can decrease the overall dewatering rate compared to wastewater sludge, as reported by [25]. 
FS from lined pit latrines had significantly slower rates of dewatering than FS from septic tanks, except for Lined_JP and Septic_UG. Dewatering rates within the same technology types were not significantly different, even between different countries (i.e. septic_UG and septic_VN, Lined_UG and Lined_JP), suggesting that dewatering rate could be influenced by the types of onsite sanitation technologies. This could be due to factors such as the technology design, construction and operation (e.g. emptying frequency, waste products entering the technology). This also illustrates the importance of designing solutions for the local context based on different types of onsite sanitation technologies, and conducting laboratory and pilot-scale experiments to validate the design of dewatering technologies [49].

Another aspect illustrated by the confidence intervals in Figure 1, is the increased variability of FS results compared to wastewater sludge. This is not surprising, as wastewater is homogenized during transport in the sewer, and samples were collected from homogenization tanks at centralized treatment plants. FS is not homogenized, and samples were collected from individual pits or tanks at the household level. Storage tanks or settling-thickening tanks could be a way to reduce this variability at FS treatment plants, and facilitate dewatering operations, but they would have to be quite large. For example, in Japan where there are around 1,000 FS treatment plants, storage tanks typically have a volume of three times the daily treatment capacity for equalization [50].

\section{Dewaterability (\%TS final)}

\%TS final, reported in Figure 2, was used as a metric of sludge dewaterability, and the results were variable between sample categories. The $\% \mathrm{TS}_{\text {final }}$ of Septic_VN of 1112 \%TS (75\% confidence interval of bootstrap median) and Johkasou_JP of 6-9 \%TS were significantly lower than of Primary_CH of 12-15 \%TS. The \%TS final $_{\text {of }}$ all types of 
FS except for Johkasou_JP was significantly higher than Activated_CH of 5-6 \%TS and Digested_CH of 8-9\%TS. Johkasou_JP had a similar \%TS final $_{\text {to }}$ th that of Activated_CH and Digested_CH. The similarity of Johkasou_JP and wastewater sludge is likely due to the similarity of treatment technologies, as most johkasou employ the activated sludge process [30]. Results for septic tank and pit latrine FS indicate that some types of FS could have a higher dewaterability than activated sludge and digested wastewater sludge; however, the higher dewaterability associated with high sand contents may pose a negative impact on FS resource recovery and final disposal, as mentioned below.

In contrast to the dewatering rate, dewaterability was different between FS from the same type of onsite sanitation technology. Whereas no significant difference was observed between Lined_UG (16-18 \%TS) and Lined_JP (17-21 \%TS), Septic_UG (14-

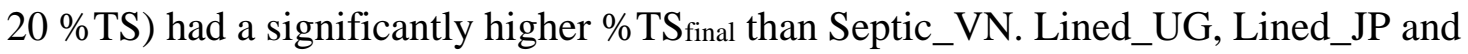
Septic_UG had a significantly higher \%TS final than Septic_VN. In contrast to the CST results, these results indicate that dewatering of FS cannot be predicted based on the onsite sanitation technology. In addition, based on the size of confidence intervals in Table 2, the variability of FS had a smaller influence on dewaterability than dewatering rate.

\section{Influence of faecal sludge characteristics on the dewatering performance}

Multiple linear regression analysis with bootstrapping was used to identify analysed characteristics of FS that have a strong correlation to dewatering performance. All of the FS samples were analyzed together, other than Johkasou_JP due to its similarity to wastewater sludge. The results of the analyses are presented in Figure 3 as the $\% R^{2}$ of

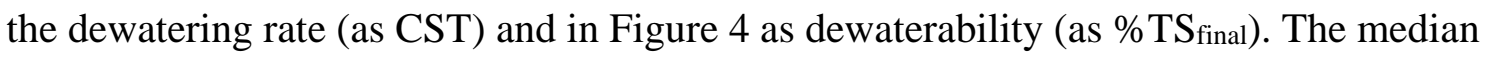
$R^{2}$ of 1,000 bootstrapping experiments was 0.67 for CST and 0.76 for $\% \mathrm{TS}$ final, which are reasonable considering the large variability of FS characteristics. 
As shown in Figure 3, characteristics related to the electrochemical properties of sludge had the largest contribution to $R^{2}$ in the CST regression model. $\mathrm{NH}_{4}-\mathrm{N}$ (mg/g TS) had a median relative importance of 22\%, surface charge (meq/g TS) of 20\%, EC $(\mathrm{mS} / \mathrm{cm})$ of $12 \%$, and crude protein (mg/g TS) of 12\%. NH4-N and EC positively correlated to increased CST, whereas surface charge and crude protein negatively correlated.

These results are similar to those observed with wastewater sludge. Cations play an important role in the dewatering of wastewater sludge. A high concentration of monovalent cations, such as $\mathrm{NH}_{4}{ }_{2}^{+}, \mathrm{Na}^{+}$and $\mathrm{K}^{+},-\mathrm{N}$ destabilize flocs and increase CST (i.e. decrease dewatering rate) by replacing divalent cations [51-53]. In this study, an increase of $\mathrm{NH}_{4}-\mathrm{N}$ was observed to also correlate to increase CST. However, this study did not investigate $\mathrm{Na}^{+}$and $\mathrm{K}^{+}$, which could also have had an impact. The increase in CST with a decrease in surface charge is likely due to electrostatic forces on the sludge surface that repel particles [20, 54, 55]. The influence of EC on CST is likely due to the correlation to $\mathrm{NH}_{4}-\mathrm{N}$ ( $r=0.6$, see supplemental material Table S2). High $\mathrm{NH}_{4}-\mathrm{N}$ concentrations could also inhibit anaerobic digestion which could influence dewatering rate $[56,57]$. It was hypothesized that crude protein as a metric of EPS would correlate to increased CST, as protein is a major component of EPS, and EPS increased CST in wastewater sludge $[58,59]$. However, crude protein correlated to a decreased CST, which could be due to a poor correlation between crude protein and EPS, as EPS is also comprised of carbohydrates. Crude protein was also negatively correlated to $\mathrm{NH}_{4}-\mathrm{N}$ ( $r=0.5$, see supplemental material Table S2), which did correlate to an increased CST.

As shown in Figure 4, characteristics related to the solid properties of sludge had the largest contribution to $R^{2}$ in the $\% \mathrm{TS}$ final regression model. Sand content (\%TS) had a median relative importance of 31\%, TVS (\%TS) of $18 \%$ and TS (mg/L) of $10 \%$. 
Surface charge (meq/g TS) and COD (mg/g TS) were also significant with median relative importance of $13 \%$ and $11 \%$, respectively. Other than surface charge, the characteristics that correlated to dewaterability were different to those that correlated to the dewatering rate.

Sand content and TVS accounted for almost $50 \%$ of $R^{2}$. TVS correlated to a decreased \%TS final. This is in line with results from wastewater sludge. Skinner et al. [24] observed that TVS correlated to decreased dewaterability of wastewater sludge. COD also correlated to a decreased \%TS final as COD and TVS are both metrics of organic matter in sludge. In contrast, sand content correlated to an increased \%TS final. This is also similar to previous observations, as inorganic particles measured as sand or ash have been observed to increase dewaterability [23]. This can be explained as inorganics having weaker or no surface charge, in comparison to organics, which have a lower compressibility, and can also provide channels for the drainage of free water.

However, high \%TS final of FS may pose a negative impact on FS resource recovery and final disposal. For example, Unlined_UG that was not included into multiple regression analysis due to the small sample size, had a sand content of 45$69 \% \mathrm{TS}$ and a \%TS final of 22-37\% (see supplemental material Table S1). Although its $\% \mathrm{TS}_{\text {final }}$ was high, this high concentration of sand contents would cause difficulties for resource recovery from sludge (e.g. incineration [15]), and increased costs for disposal in landfills.

\section{Application and limitations of results}

FS characteristics that were identified to correlate to dewatering rate and dewaterability based on bootstrapping multiple linear regression models could be used to predict dewatering performance, and may explain the differences in dewatering rate and dewaterability across the FS sample categories examined in this study. To evaluate this 
potential, Figure 5 and Figure 6 include sludge characteristics for the different sample categories that had a significant relative importance in the regression models.

Public_Septic_VN and Unlined_UG were excluded from this evaluation due to small sample number.

Lined_UG had a significantly lower CST than Septic_UG and Septic_VN, and Lined_JP had a significantly lower CST than Septic_VN (see Figure 1). These results could be explained by $\mathrm{NH}_{4}-\mathrm{N}$ and EC, that had a significant relative importance in the regression model for CST. As shown in Figure 5, NH4-N and EC that correlated with increased CST was significantly different between sample categories. Lined_UG and Lined_JP had significantly higher median $\mathrm{NH}_{4}-\mathrm{N}$ and EC than Septic_VN and Septic_UG: 52-152 mg/g TS vs. 7-54 mg/g TS; $11-17$ mS/cm vs. 2-6 mS/cm. High $\mathrm{NH}_{4}-\mathrm{N}$ and EC are characteristic of FS from lined pit latrines due to more concentrated FS with no overflow $[26,60]$. These results imply that the $\mathrm{NH}_{4}-\mathrm{N}$ and EC could be responsible for the observed poor dewatering performance of pit latrine FS compared to septic tank FS. If so, this result could be very valuable in the design and operation of onsite sanitation technologies, and treatment technologies. In contrast, surface charge (see Figure 5) and crude protein (see supplemental material Table S1) which did have a strong correlation to CST were not significantly different between sample categories. Results for crude protein were not significantly different between sample categories and are therefore not included in Figure 5.

Septic_UG, Lined_UG and Lined_JP had a significantly higher \%TS final than Septic_VN (see Figure 2). These results could be explained by TVS, COD and sand content, that had a significant relative importance in the regression model for $\% \mathrm{TS}$ final, because as shown in Figure 6, TVS, COD and sand content were significantly different among the sample categories. TVS that correlated to decreased \%TS final $_{\text {were }}$ 
significantly higher for Septic_VN (71-77\%TS) than for Septic_UG (49-60\%TS), Lined_UG (53-60\%TS) and Lined_JP (59-67\%TS). COD that correlated to decreased \%TS final were significantly higher for Septic_VN (1,152-1,345 mg/g TS) than for Lined_UG (962-1,112 mg/g TS). However, results for Lined_JP indicate limitations of explaining the dewaterability by single characteristics. Lined_JP had significantly lower sand content (7-9\%TS) than the other types of FS (11-32\%TS), which based on this explanation would be in contradiction to Lined_JP having significantly higher \%TS final than Septic_VN (see Figure 2). These results are likely due to the interrelation of multiple characteristics having an influence on dewaterability. Further, as mentioned in the previous section, high sand contents would pose a negative impact on resource recovery and final disposal although it was strongly correlated to

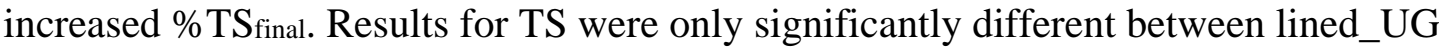
and lined_JP and are therefore not included in Figure 6.

The different observed concentrations of TVS, COD and sand content in the different types of FS, are due to the wide ranging differences in the design, construction and operation of onsite technologies, including the solids retention time, influx of sand due to poor construction, and types and volumes of waste products. For example, lined pit latrines in Japan are made of Fibre-Reinforced Plastic and are constructed at factories, whereas lined-pit latrine in Uganda are constructed in situ with bricks. This difference alone could contribute to the higher sand concentrations that were observed for Lined_UG FS. Thus, differences in types of construction, different materials, and modes of operation, could potentially also provide ways to predict dewaterability of FS.

\section{Conclusions}

Highly variable dewatering performance of FS greatly complicates the reliable design and operation of treatment plants. These results provide the first published reference 
comparing dewatering rates and dewaterability of FS from different regions around the world. The results identify potential characteristics that could explain and predict the high variability that is observed in the field. Future research in this area is needed for the improved design and operation of FS treatment plants. Findings include:

- FS samples had a significantly higher CST, indicating lower dewatering rate than wastewater sludge;

- FS samples had an equal or higher \%TS final compared to wastewater sludge;

- However, if higher \%TS final are caused by high sand contents, it would pose a negative impact on resource recovery and final disposal;

- Electrochemical properties had the strongest correlation to FS dewatering rate, and solid properties on FS dewaterability;

- FS characteristics that were strongly correlated to dewatering could explain observed differences in dewatering between different types of FS;

- Future research is needed to develop predictive models of sludge characteristics on dewatering, based on a fundamental understanding of FS dewatering mechanisms.

\section{References}

1. Cairns-Smith S, Hill H, Nazarenko E. Working Paper Urban Sanitation: Why a portfolio of solutions is needed. The Boston Consulting Group. 2014.

2. Harada H, Strande L, Fujii S. Challenges and Oppotuniteis of Faecal Sludge Management for Global Sanitation. In: Katsumi T and Hashimoto S, editors. Towards Future Earth: Challenges and Progress of Global Environmental Studies. Tokyo (Japan): Kaisei Publshing; 2016. p. 81-100. (ISBN 978-4-87603500-7). 
3. Strande L. The global situation. In: Strande L, Ronteltap M, Brdjanovic D, editors. Faecal sludge management: Systems approach for implementation and operation. London (UK): IWA Publishing; 2014. p. 1-14.

4. Peal A, Evans B, Blackett I, Hawkins P, Heymans C. A Review of Fecal Sludge Management in 12 Cities. Washington (DC): World Bank - Water and Sanitation Program; 2015.

5. Schoebitz L, Niwagaba CB, Strande L. Kampala, Uganda: Sanitation service delivery context analysis and mapping of excreta flows along the sanitation service chain and throughout the city. Dübendorf (Switzerland): Eawag/Sandec; 2016. (available at: www.eawag.ch/fileadmin/Domain1/Abteilungen/sandec/publikationen/EWM/SF D/SFD_Sandec_Kampala.pdf, last access on 14 July 2017)

6. Brandes K, Schoebitz L, Kimwaga R, Strande L. Dar es Salaam Tanzania: Sanitation service delivery context analysis and mapping of excreta flows along the sanitation service chain and throughout the city. Dübendorf (Switzerland): Eawag/Sandec; 2015. (available at: www.eawag.ch/fileadmin/Domain1/Abteilungen/sandec/publikationen/EWM/SF D/SFD_Sandec_Dar_es_Salaam.pdf, last access on 14 July 2017)

7. Brandes K, Schoebitz L, Nguyen VA, Strande L. Hanoi, Vietnam: Sanitation service delivery context analysis and mapping of excreta flows along the sanitation service chain and throughout the city. Dübendorf (Switzerland): Eawag/Sandec; 2016. (available at: www.eawag.ch/fileadmin/Domain1/Abteilungen/sandec/publikationen/EWM/SF D/SFD_Sandec_Hanoi.pdf, last access on 14 July 2017)

8. Harada H, Schoebitz L, Strande L. Danang, Vietnam: Sanitation service delivery context analysis and mapping of excreta flows along the sanitation service chain and throughout the city. Dübendorf (Switzerland): Eawag/Sandec; 2015. (available at: www.eawag.ch/fileadmin/Domain1/Abteilungen/sandec/publikationen/EWM/SF D/SFD_Sandec_Danang.pdf, last access on 14 July 2017)

9. Harada H, Schoebitz L, Strande L. Nonthaburi, Thailand: Sanitation service delivery context analysis and mapping of excreta flows along the sanitation service chain and throughout the city. Dübendorf (Switzerland): Eawag/Sandec; 2015. (available at: 
www.eawag.ch/fileadmin/Domain1/Abteilungen/sandec/publikationen/EWM/SF D/SFD_Sandec_Nonthaburi.pdf, last access on 14 July 2017)

10. Hutton G, Haller L. Evaluation of the costs and benefits of water and sanitation improvements at the global level. Water, Sanitation, and Health, Protection of the Human Environment, Geneva (Switzerland): World Health Organization; 2004.

11. Mara D, Lane J, Scott B, Trouba D. Sanitation and health. PLoS Med. 2010;7(11):e1000363.

12. Seck A, Gold M, Niang S, Mbéguéré M, Strande L. Faecal sludge drying beds: Increasing drying rates for fuel resource recovery in Sub-Saharan Africa. J Water Sanit Hyg Dev. 2015;5(1):72-80.

13. Gold M, Dayer P, Faye MCAS, Clair G, Seck A, Niang S, Strande L. Locally produced natural conditioners for dewatering of faecal sludge. Environ Technol. 2016;37(21):1-13.

14. Sonko EhM, Mbéguéré M, Diop C, Niang S, Strande L. Effect of hydraulic loading frequency on performance of planted drying beds for the treatment of faecal sludge. J Water Sanit Hyg Dev. 2014;4(4):633-641.

15. Gold M, Ddiba DI, Seck A, Sekigongo P, Diene A, Diaw S, Niang S, Niwagaba CB, Strande L. Faecal sludge as a solid industrial fuel: A pilot-scale study. J Water Sanit Hyg Dev. in press.

16. Niwagaba CB, Mbéguéré M, Strande L. Faecal sludge quantification, characterization and treatment objectives. In: Strande L, Ronteltap M, Brdjanovic D, editors. Faecal sludge management: Systems approach for implementation and operation. London (UK): IWA Publishing; 2014. p. 19-44.

17. Mikhael G, Robbins DM, Ramsay JE, Mbéguéré M. Methods and Means for Collection and Transport of Faecal Sludge. In: Strande L, Ronteltap M, Brdjanovic D, editors. Faecal sludge management: Systems approach for implementation and operation. London (UK): IWA Publishing; 2014. p. 141-154.

18. Mikkelsen LH, Keiding K. Physico-chemical characteristics of full scale sewage sludges with implications to dewatering. Water Res. 2002;36(10):2451-2462.

19. Karr PR, Keinath TM. Influence of particle size on sludge dewaterability. J Water Pollut Control Fed. 1978;50(8):1911-1930.

20. Kopp J, Dichtl N. Influence of Surface Charge and Exopolysaccharides on the Conditioning Characteristics of Sewage Sludge. In: Hahn HH, Hoffmann E, 
Ødegaard H, editors. Chemical Water and Wastewater Treatment V:

Proceedings of the 8th Gothenburg Symposium 1998 September 07-09, 1998 Prague, Czech Republic. Berlin, Heidelberg (Germany): Springer Berlin Heidelberg; 1998. p. 285-296.

21. Turovskiy IS, Mathai P. Wastewater sludge processing. Hoboken (NJ): John Wiley \& Sons; 2006.

22. Christensen ML, Keiding K, Nielsen PH, Jørgensen MK. Dewatering in biological wastewater treatment: A review. Water Res. 2015;82:14-24.

23. German Association for Water. WaWD Merkblatt DWA-M 383 Kennwerte der Klärschlammentwässerung (leaflet DWA - M 383 Characteristic values for wastewater sludge dewatering). Hennef (Germany): Deutsche Vereinigung für Wasserwirtschaft, Abwasser und Abfall (DWA) (German Association for Water, Wastewater and Waste); 2008.

24. Skinner S, Studer L, Dixon D, Hillis P, Rees C, Wall R, Cavalida R, Usher S, Stickland A, Scales P. Quantification of wastewater sludge dewatering. Water Res. 2015;82:2-13.

25. United States Environmental Protection Agency (US EPA). Handbook of septage treatment and disposal. Cincinnati (OH); 1984.

26. Heinss U, Larmie SA, Strauss M. Solids separation and pond systems for the treatment of faecal sludges in the tropics. Lessons learnt and recommendations for preliminary design. Dübendorf (Switzerland): Eawag/Sandec; 1998.

27. Nakagiri A, Kulabako RN, Nyenje PM, Tumuhairwe JB, Niwagaba CB, Kansiime F. Performance of pit latrines in urban poor areas: A case of Kampala, Uganda. Habitat Int. 2015;49:529-537.

28. Tilley E, Ulrich L, Lüthi C, Reymond P, Zurbrügg C. Compendium of sanitation systems and technologies. Dübendorf (Switzerland): Eawag; 2014.

29. Harada H, Dong NT, Matsui S. A measure for provisional-and-urgent sanitary improvement in developing countries: septic-tank performance improvement. Wat Sci Tech. 2008;58(6):1305-1311.

30. Japan Education Center of Environmental Sanitation (JECES). Johkasou systems for domestic wastewater treatment $5^{\text {th }}$ edition. Tokyo (Japan): JECES; 2012.

31. Department of Waste, Water, Energy (AMWEL), Canton Zurich. Factsheets wastewater treatment plants. Zurich (Switzerland): Canton Zurich; 2016. 
32. Kopp J, Dichtl N. Prediction of full-scale dewatering results by determining the water distribution of sewage sludges. Wat Sci Tech. 2000;42(9):141-149.

33. Kopp J, Dichtl N. Influence of the free water content on the dewaterability of sewage sludges. Wat Sci Tech. 2001;44(10):177-183.

34. Denkert R. Entwässerung mit Dekantierzentrifugen (Dewatering with Decanting centrifuges), ATV-Seminar 10/93 - Schlammentwässerung (Sludge dewatering), Chapter. 7.1-7.26. 1995.

35. American Public Health Association (APHA), American Water Work Association (AWWA), Water Environmental Federation (WEF). Standard methods for the examination of water and wastewater. $21^{\text {st }}$ edition. Washington (DC): APHA; 2005.

36. Peng G, Ye F, Li Y. Comparative Investigation of Parameters for Determining the Dewaterability of Activated Sludge. Water Environ Res. 2011;83(7):667-671.

37. Vesilind PA. Capillary Suction Time as a Fundamental Measure of Sludge Dewaterability. J Water Pollut Control Fed. 1988;60(2):215-220.

38. Mariotti F, Tomé D, Mirand PP. Converting Nitrogen into Protein-Beyond 6.25 and Jones' Factors. Crit Rev Food Sci. 2008;48(2):177-184.

39. Japan Sewage Works Association (JSWA). Gesui Shiken Houhou (Standard methods for analysis of sewage). Tokyo (Japan): JSWA; 2012.

40. Ueno K, Kina Ky. Colloid titration-A rapid method for the determination of charged colloid. J. Chem. Educ. 1985;62(7):627.

41. Tchobanoglous G, Burton FL, Stensel HD, Metcalf \& Eddy, editors. Wastewater engineering: treatment and resource recovery. New York (NY): McGraw-Hill Higher Education; 2013.

42. Schmid H, Huber A. Measuring a Small Number of Samples, and the 3v Fallacy: Shedding Light on Confidence and Error Intervals. IEEE Solid-State Circuits Magazine. 2014;6(2):52-58.

43. R Core Team. R: A language and environment for statistical computing. Vienna (Austria): R Foundation for Statistical Computing; 2017.

44. Grömping U. Relative importance for linear regression in R: the package relaimpo. J Stat Softw. 2006;17(1):139-147.

45. Bassan M, Tchonda T, Yiougo L, Zoellig H, Mahamane I, Mbéguéré M, Strande L. Characterization of faecal sludge during dry and rainy seasons in 
Ouagadougou, Burkina Faso. In: Proceedings of the 36th WEDC International Conference 2013, Nakuru, Kenya.

46. Koottatep T, Surinkul N, Polprasert C, Kamal A, Koné D, Montangero A, Heinss U, Strauss M. Treatment of septage in constructed wetlands in tropical climate: lessons learnt from seven years of operation. Wat Sci Tech. 2005;51(9):119-126.

47. Kengne I, Kengne ES, Akoa A, Bemmo N, Dodane P-H, Koné D. Vertical-flow constructed wetlands as an emerging solution for faecal sludge dewatering in developing countries. J Water Sanit Hyg Dev. 2011;1(1):13-19.

48. Semiyaga S, Okure MAE, Niwagaba CB, Nyenje PM, Kansiime F. Dewaterability of faecal sludge and its implications to faecal sludge management in urban slums. Int. J. Environ. Sci. Technol. 2017;14(1):151-164.

49. Dodane P-H, Ronteltap M. Unplanted drying beds. In: Strande L, Ronteltap M, Brdjanovic D, editors. Faecal sludge management: Systems approach for implementation and operation. London (UK): IWA Publishing; 2014. p. 141-154.

50. Japan Waste Management Association (JWMA). Odei saisei shori center tou shisetsuseibi no keikaku sekkei yoryo (Guideline for planning and design of sludge recycling center development). Tokyo (Japan): JWMA; 2006.

51. Biggs CA, Ford AM, Lant PA. Activated sludge flocculation: direct determination of the effect of calcium ions. Wat Sci Tech. 2001;43(11):75-82.

52. Higgins MJ, Novak JT. The Effect of Cations on the Settling and Dewatering of Activated Sludges: Laboratory Results. Water Environ Res. 1997;69(2):215-224.

53. Sobeck DC, Higgins MJ. Examination of three theories for mechanisms of cation-induced bioflocculation. Water Res. 2002;36(3):527-538.

54. Liu Y, Fang HHP. Influences of Extracellular Polymeric Substances (EPS) on Flocculation, Settling, and Dewatering of Activated Sludge. Crit Rev Env Sci Tec. 2003;33(3):237-273.

55. Wilén B-M, Jin B, Lant P. The influence of key chemical constituents in activated sludge on surface and flocculating properties. Water Res. 2003;37(9):2127-2139.

56. Chaggu EJ, Sanders W, Lettinga G. Demonstration of anaerobic stabilization of black water in accumulation systems under tropical conditions. Bioresour Technol. 2007;98(16):3090-3097. 
57. McCarty PL, McKinney RE. Salt Toxicity in Anaerobic Digestion. J Water Pollut Control Fed. 1961;33(4):399-415.

58. Houghton JI, Stephenson T. Effect of influent organic content on digested sludge extracellular polymer content and dewaterability. Water Res. 2002;36(14):3620-3628.

59. Houghton JJ, Quarmby J, Stephenson T. Municipal wastewater sludge dewaterability and the presence of microbial extracellular polymer. Wat Sci Tech. 2001;44(2-3):373-379.

60. Strauss M, Larmie S, Heinss U. Treatment of sludges from on-site sanitationLow-cost options. Wat Sci Tech. 1997;35(6):129-136. 
Table 1. Country, type of sludge (FS = faecal sludge, WWS = wastewater sludge), technology, name of sample category and $n=$ number of samples analysed in this study.

\begin{tabular}{lllll}
\hline Country & $\begin{array}{l}\text { Type of } \\
\text { sludge }\end{array}$ & Technology & $\begin{array}{l}\text { Name of sample } \\
\text { category }\end{array}$ & n \\
\hline Vietnam & FS & Septic tank of households & Septic_VN & 10 \\
Vietnam & FS & $\begin{array}{l}\text { Septic tank of public pay-for-use } \\
\text { toilets }\end{array}$ & Public_Septic_VN & 4 \\
Uganda & FS & $\begin{array}{l}\text { Septic tank } \\
\text { Unlined pit latrine }\end{array}$ & Septic_UG & 13 \\
Uganda & FS & Unlined_UG & 5 \\
Uganda & FS & Lined pit latrine & Lined_UG & 16 \\
Japan & FS & Lined pit latrine & Lined_JP & 16 \\
Japan & FS & Johkasou tank & Johkasou_JP & 9 \\
Switzerland & WWS & Primary sedimentation tank & Primary_CH & 6 \\
Switzerland & WWS & Aeration tank & Activated_CH & 6 \\
Switzerland & WWS & Anaerobic digester & Digested_CH & 6 \\
\hline
\end{tabular}


Table 2. Descriptive statistics (med.=median, S.D.=standard deviation) of physical and chemical characteristics of all FS sample categories.

\begin{tabular}{|c|c|c|c|c|c|c|c|c|c|c|}
\hline & $n$ & & pH & EC & TS & TVS & COD & $\begin{array}{c}\mathrm{NH}_{4-} \\
\mathrm{N} \\
\end{array}$ & CST & $\%$ TS $_{\text {final }}$ \\
\hline $\begin{array}{l}\text { Name of sample } \\
\text { category }\end{array}$ & & & - & $\mathrm{mS} / \mathrm{cm}$ & $\%$ & $\% \mathrm{TS}$ & $\mathrm{g} / \mathrm{L}$ & $\mathrm{mg} / \mathrm{L}$ & $\begin{array}{l}\mathrm{sec} /(\mathrm{g} \\
\mathrm{TS} / \mathrm{L})\end{array}$ & \%TS \\
\hline \multirow[t]{3}{*}{ Septic_VN } & 10 & Mean & 7.7 & 2.3 & 2.1 & 73.2 & 24.9 & 184 & 23 & 11 \\
\hline & & Med. & 7.8 & 2.0 & 1.8 & 75.5 & 22.1 & 183 & 22 & 12 \\
\hline & & S.D. & 0.5 & 1.3 & 1.3 & 6.1 & 14.2 & 77 & 9 & 2 \\
\hline \multirow[t]{3}{*}{ Public_septic_VN } & 4 & Mean & 7.4 & 5.6 & 3.2 & 56.5 & 33.9 & 598 & 11 & 13 \\
\hline & & Med. & 7.7 & 3.7 & 1.7 & 56.0 & 17.3 & 379 & 13 & 13 \\
\hline & & S.D. & 1.1 & 5.6 & 4.2 & 12.8 & 45.8 & 691 & 4 & 7 \\
\hline \multirow[t]{3}{*}{$\begin{array}{l}\text { Septic_UG } \\
\text { Se_t }\end{array}$} & 13 & Mean & 7.4 & 5.7 & 2.0 & 50.9 & 16.3 & 579 & 28 & 18 \\
\hline & & Med. & 7.7 & 4.9 & 1.8 & 57.0 & 13.8 & 626 & 27 & 14 \\
\hline & & S.D. & 0.7 & 5.9 & 1.6 & 18.9 & 13.6 & 548 & 18 & 13 \\
\hline $\begin{array}{l}\text { Septic tank values } \\
\text { from literature }{ }^{1}\end{array}$ & - & $\begin{array}{l}\text { Range } \\
\text { of } \\
\text { mean } \\
\text { values }\end{array}$ & - & $2.4-5.0$ & $\begin{array}{c}0.8- \\
4.0\end{array}$ & $\begin{array}{c}55- \\
71\end{array}$ & $8.2-37.7$ & $\begin{array}{l}150- \\
600\end{array}$ & $3-21$ & - \\
\hline \multirow[t]{3}{*}{ Lined_UG } & 16 & Mean & 7.8 & 14.6 & 2.2 & 54.0 & 21.6 & 1654 & 49 & 20 \\
\hline & & Med. & 7.8 & 13.6 & 1.7 & 56.0 & 20.8 & 1498 & 56 & 17 \\
\hline & & S.D. & 0.2 & 7.7 & 1.0 & 12.0 & 8.9 & 848 & 22 & 9 \\
\hline \multirow[t]{3}{*}{ Lined_JP } & 16 & Mean & 7.4 & 12.6 & 1.1 & 60.6 & 10.9 & 1417 & 63 & 18 \\
\hline & & Med. & 7.3 & 12.4 & 1.1 & 63.0 & 9.8 & 1290 & 44 & 19 \\
\hline & & S.D. & 0.6 & 2.5 & 0.3 & 17.9 & 4.5 & 362 & 57 & 6 \\
\hline $\begin{array}{l}\text { Lined pit values } \\
\text { from literature }\end{array}$ & & $\begin{array}{c}\text { Range } \\
\text { of } \\
\text { mean } \\
\text { values }\end{array}$ & - & 18.1 & $\begin{array}{c}0.9- \\
5.2\end{array}$ & $\begin{array}{l}57- \\
64\end{array}$ & $\begin{array}{l}34.0- \\
65.5\end{array}$ & $\begin{array}{l}1418- \\
2100\end{array}$ & - & - \\
\hline \multirow[t]{3}{*}{ Unlined_UG } & 5 & Mean & 7.8 & 12.1 & 17.9 & 43.2 & 117.6 & 3175 & 10 & 30 \\
\hline & & Med. & 7.8 & 12.0 & 14.8 & 52.0 & 127.2 & 3110 & 9 & 30 \\
\hline & & S.D. & 0.2 & 3.7 & 9.5 & 15.1 & 40.8 & 839 & 4 & 10 \\
\hline \multirow[t]{3}{*}{ Johkasou_JP } & 9 & Mean & 7.0 & 2.2 & 1.0 & 74.0 & 13.2 & 239 & 66 & 9 \\
\hline & & Med. & 7.1 & 1.7 & 1.0 & 77.0 & 12.6 & 178 & 30 & 8 \\
\hline & & S.D. & 0.4 & 2.0 & 0.4 & 13.4 & 6.6 & 193 & 93 & 3 \\
\hline
\end{tabular}


Figure 1. 75\% confidence interval of the bootstrapped median of dewatering (CST) for FS and wastewater sludge. Legend: Septic_VN = septic tank of households Vietnam; Septic_UG = septic tank Uganda; Lined_UG = lined pit latrine Uganda; Lined_JP = lined pit latrine Japan; Johkasou_JP = johkasou tank Japan; Activated_CH = wastewater aeration tank Switzerland; Digested_CH = wastewater anaerobic digester Switzerland; Primary_CH = wastewater primary sedimentation tank Switzerland.

Figure 2. 75\% confidence interval of the bootstrapped median dewaterability (\%TS final) of FS and wastewater sludge. Legend: Septic_VN = septic tank of households Vietnam; Septic_UG = septic tank Uganda; Lined_UG = lined pit latrine Uganda; Lined_JP = lined pit latrine Japan; Johkasou_JP = johkasou tank Japan; Activated_CH = wastewater aeration tank Switzerland; Digested_CH = wastewater anaerobic digester Switzerland; Primary_CH = wastewater primary sedimentation tank Switzerland.

Figure 3. Relative Importance of correlation of FS characteristics to the dewatering rate (as CST (sec/(g TS/L)), calculated by bootstrapping multiple regression analysis. The figure shows bootstrapping median and 95\% confidence interval, (+) and (-) indicate the direction of influence by each characteristic.

Figure 4. Relative Importance of correlation of FS characteristics to the dewaterability (as \%TS final), calculated by bootstrapping multiple regression analysis. The figure shows bootstrapping median and 95\% confidence interval, $(+)$ and $(-)$ indicate the direction of influence by each characteristic.

Figure 5. 75\% confidence interval of the bootstrapped median of $\mathrm{NH}_{4}-\mathrm{N}$ (left), EC (center) and surface charge (right) for septic tank and lined pit latrine FS.

Figure 6. 75\% confidence interval of the bootstrapped median of sand content (left), TVS (center) and COD (right) for septic tank and lined pit latrine FS. 
Figure 1

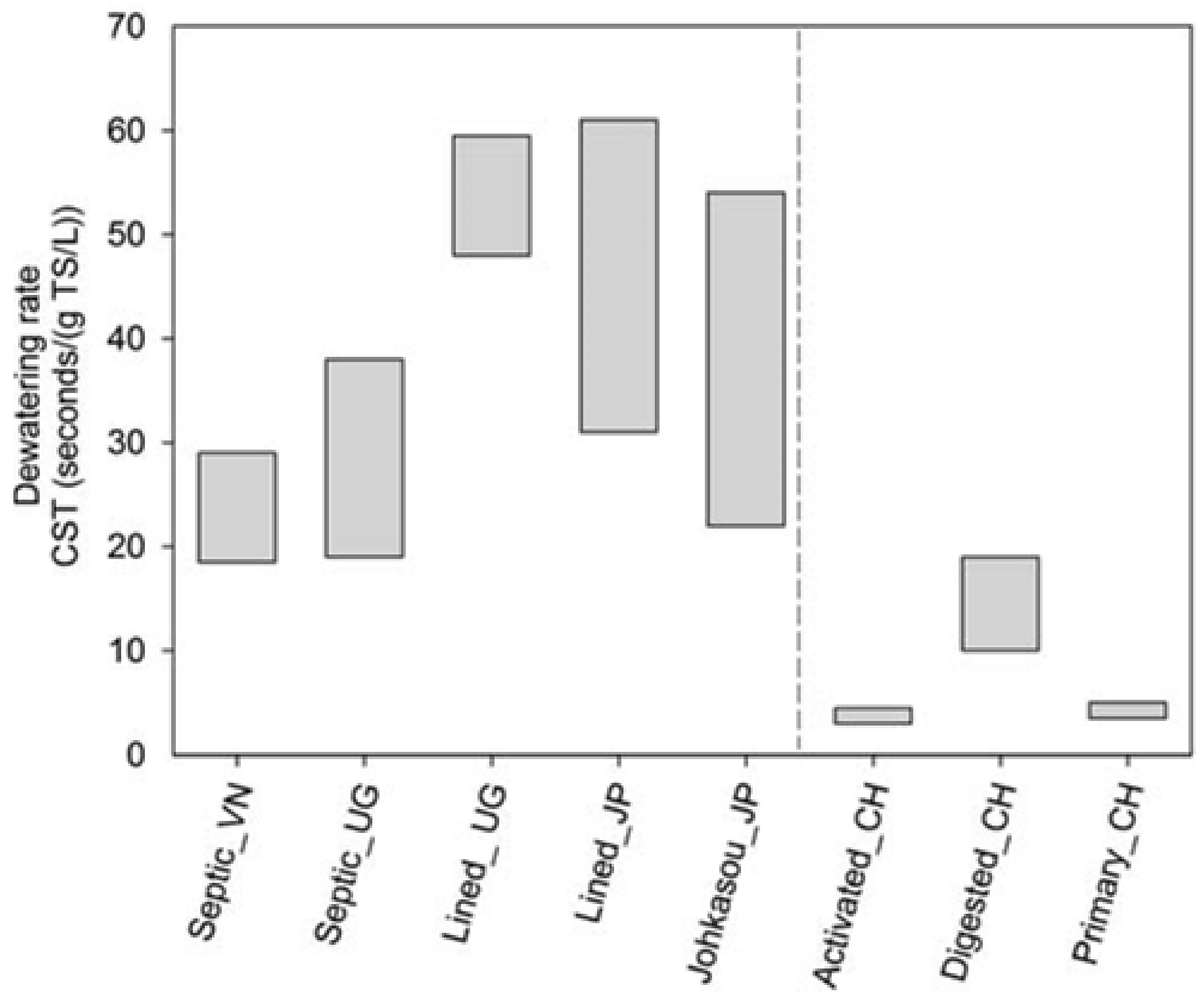


Figure 2

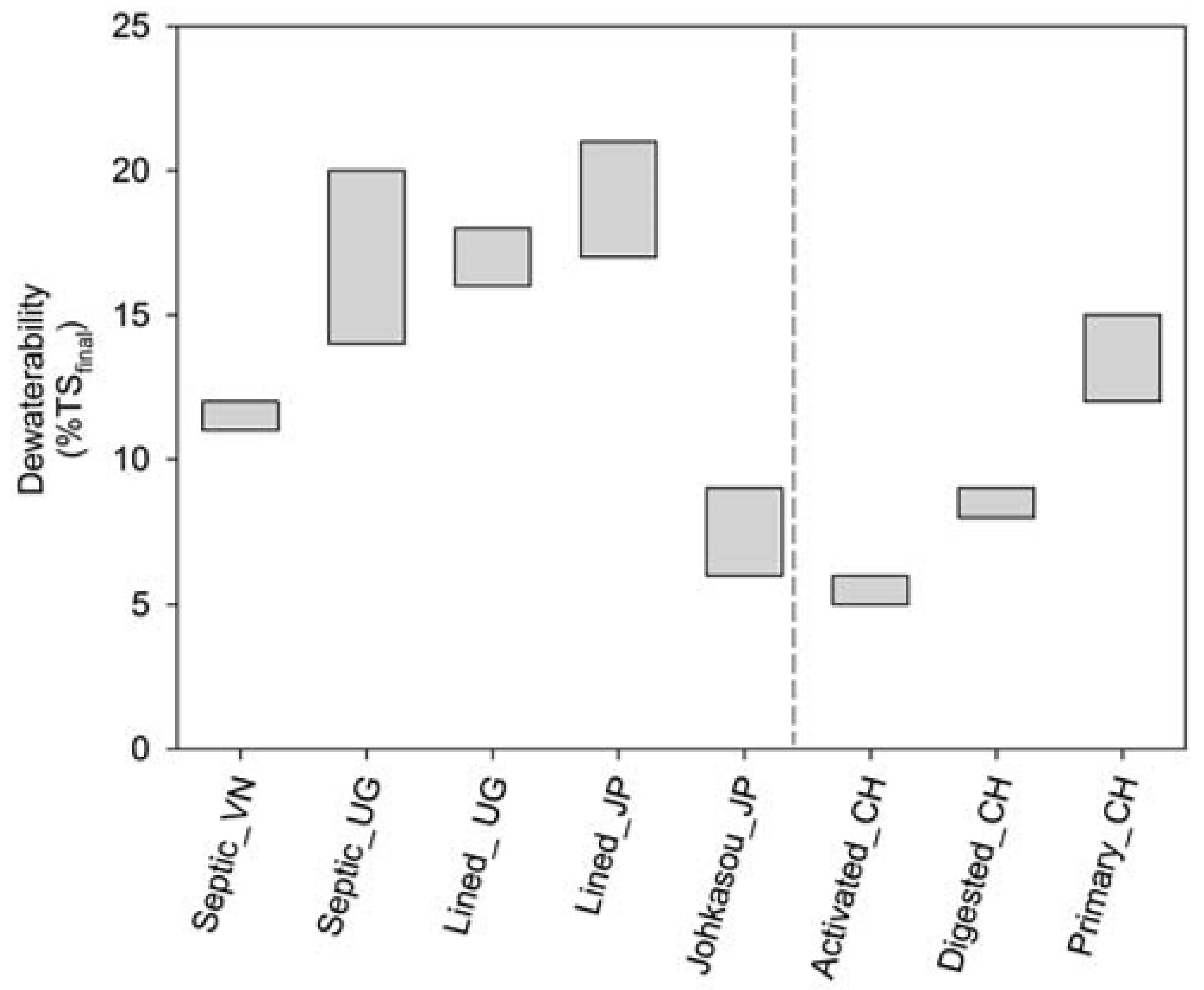




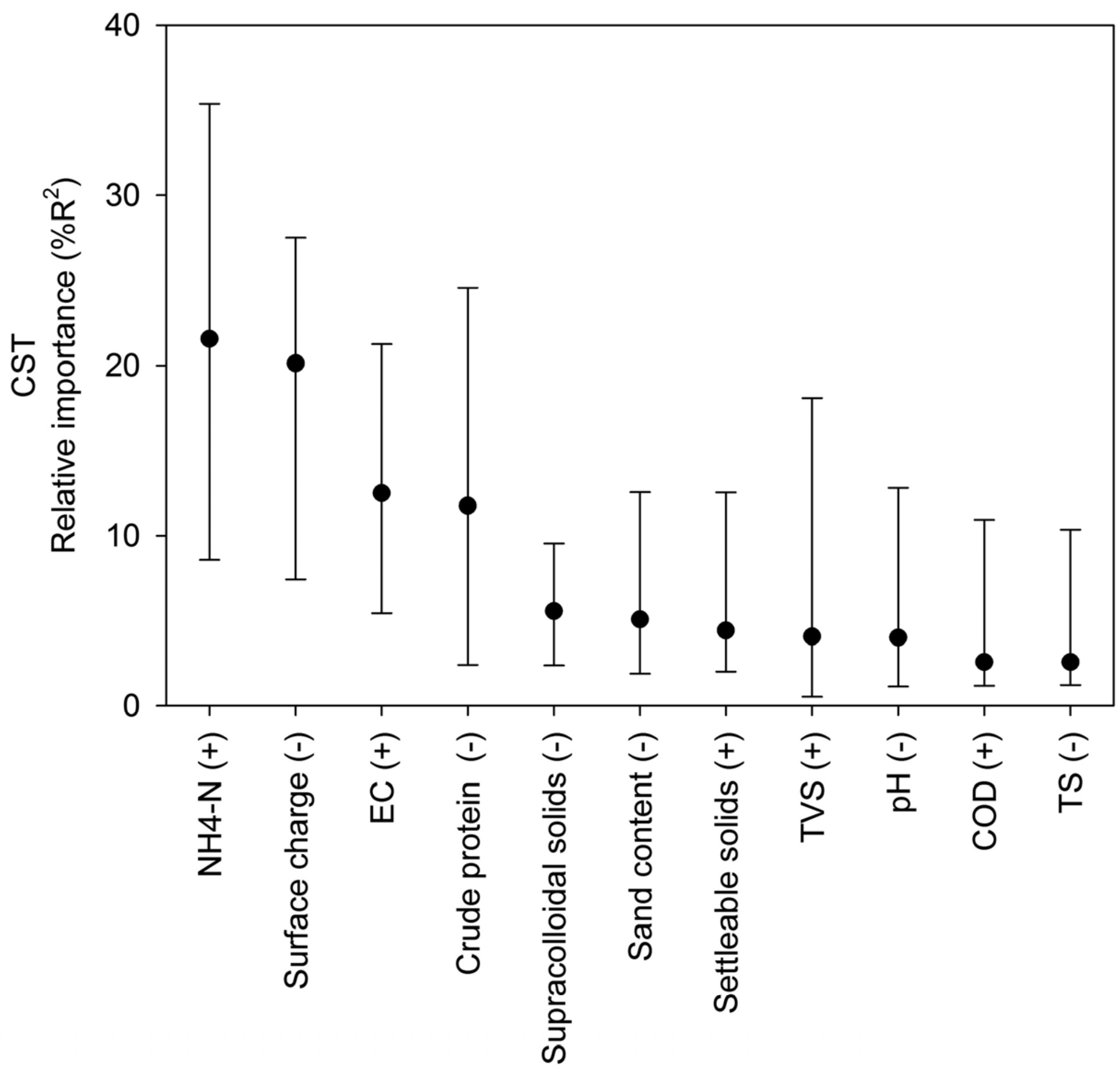


Figure 4

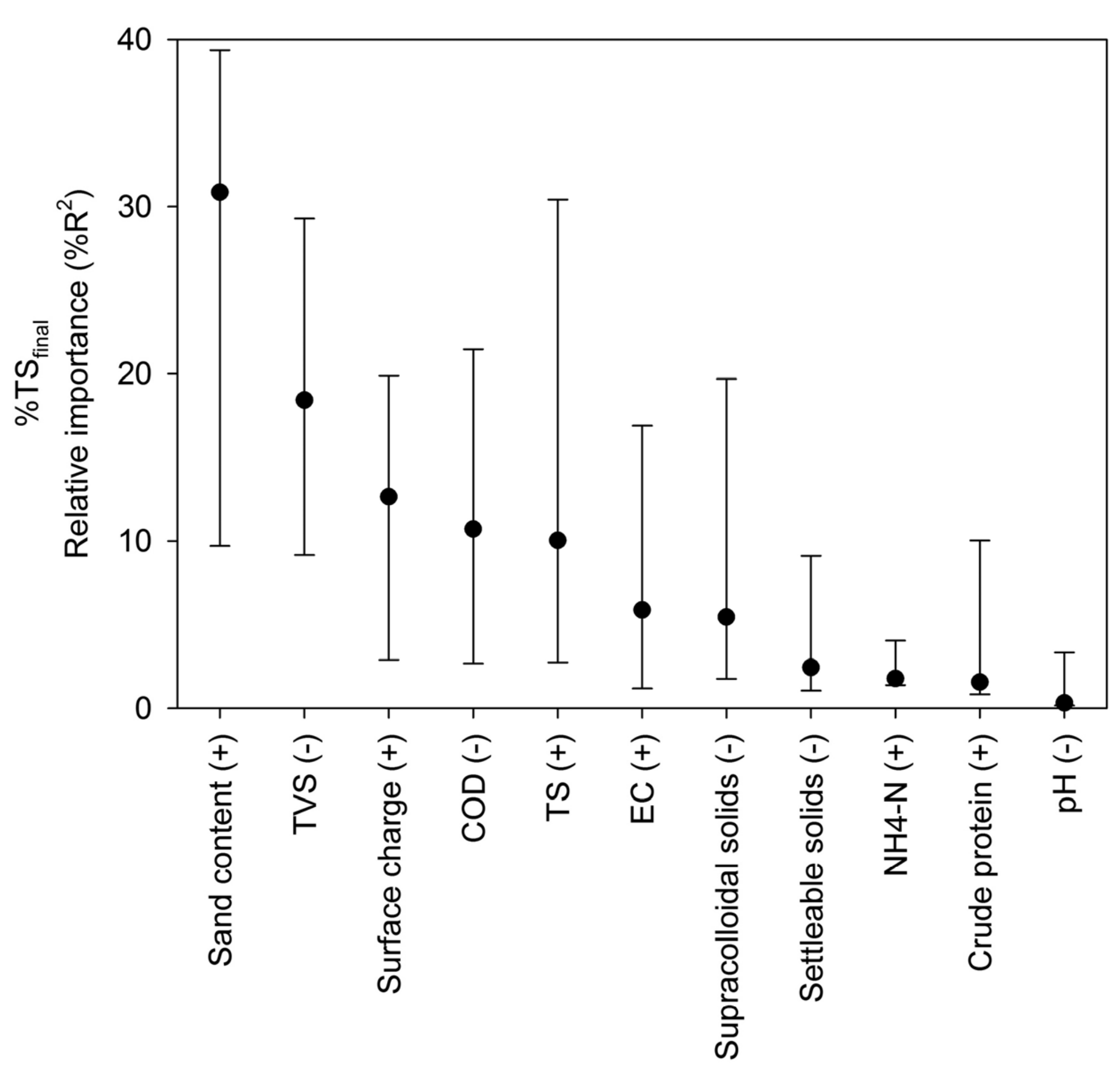



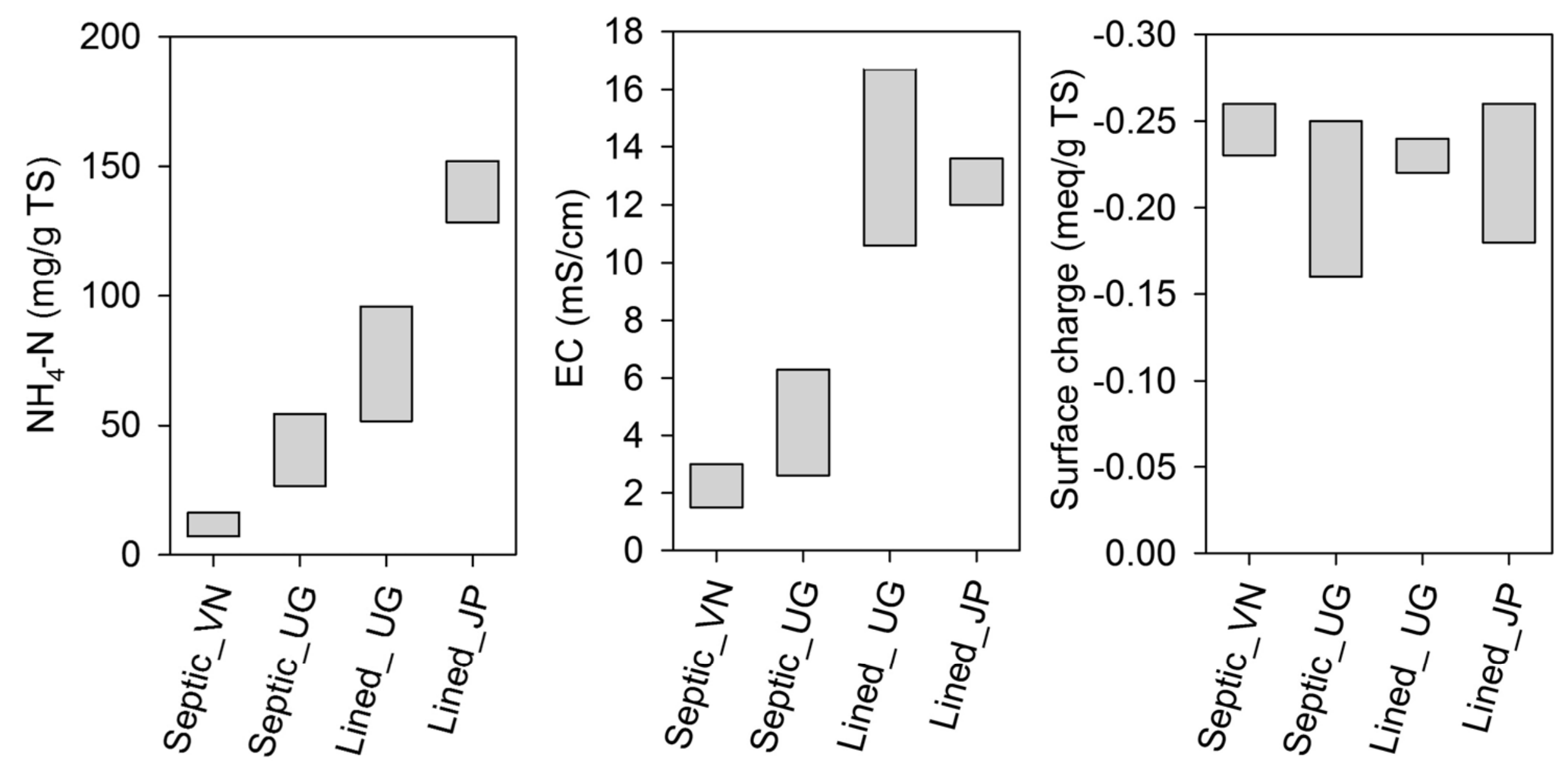
Figure 6
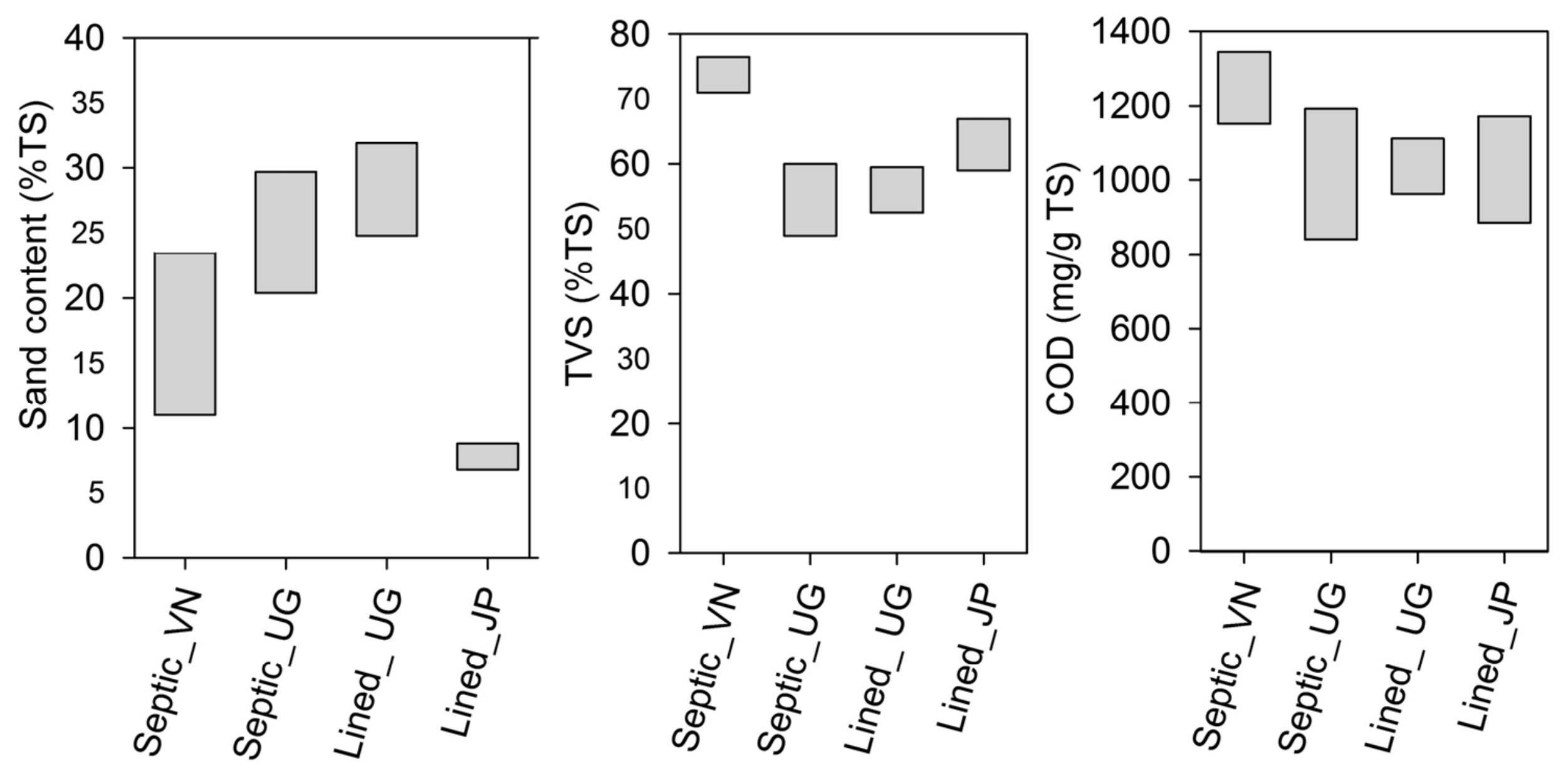